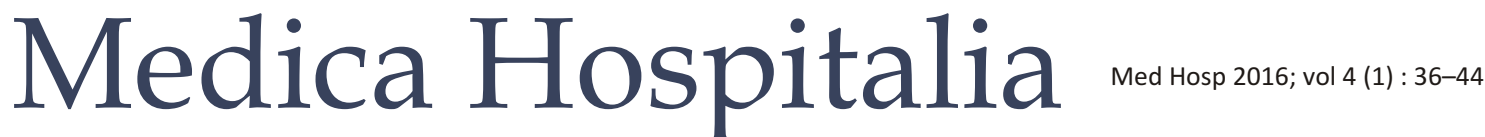

Original Article

\section{Correlation between serum level of cortisol, interleukin-10 and degree of adhesion after laparotomy and laparoscopy in rabbit with abrasion model}

\author{
Ridwan Mataram¹, Johny Sjoeib², Selamat Budiyitno² \\ ${ }^{1}$ Peserta PPDS 1 IImu Bedah, Fakultas Kedokteran UNDIP/RSUP Dr. Kariadi, Semarang \\ ${ }^{2}$ Departemen Ilmu Bedah, Fakultas Kedokteran UNDIP/RSUP Dr. Kariadi, Semarang
}

\begin{abstract}
Background : Intraperitoneal adhesions after abdominal and pelvic surgery procedures occurred almost in 95\% of cases. This research will prove the relationship between serum levels of cortisol in response to stress with increased levels of IL-10 and the degree of adhesion after laparotomy and laparoscopy

Methods : This study is an experimental laboratory, with a posttest design approach using 12 New Zealand rabbits after adaptation for 1 week were divided into 2 groups. The first group ( K1) was performed laparotomy with abration the ilium, group-2 ( K2) was performed laparoscopy with abration the ilium too. All groups taken its blood sample before and 6 hours after operation to be assessed levels of cortisol with ELISA kit. 6 days after operation (day of 7th), all group determinate and performed laparotomy, than assessed the degree of adhesion and the level of IL-10 from its peritoneal fluid. Statistical tests were used to assess defferences in the level of cortisol, IL-10 and degree do adhesion between laparotomy and laparoscopy. Data analysis was done using SPSS.

Results : There was significant difference in the level of cortisol, IL-10 and degree of adhesion among groups ( $p=0.021, p<0.001, p$ $=0.002$ ). There were negatif correlation ( high) between the level of blood cortisol with $\mathrm{IL}-10(r=-0.805, p=0.0)$ and significant negative correlation between the level of $I L-10$ with the degree of adhesion ( $r=-0,833, p=0.001)$.

Conclusion : Laparoscopic surgery can minimize the effects of systemic stress and immune response, so as to lower the incidence ofadhesion.
\end{abstract}

Keywords : Degrees of adhesion, cortisol, IL-10, laparotomy, laparoscopy

\section{Hubungan antara kadar serum kortisol, interleukin-10 dan derajat adesi pasca laparotomi dan laparoskopi pada kelinci dengan model abrasi}

\begin{abstract}
Abstrak
Latar belakang : Kejadian adesi intraperitonial pasca prosedur operasi abdomen dan pelvis adalah 95\% dari semua kasus. Penelitian ini akan membuktikan hubungan antara kadar serum kortisol sebagai penanda stress dengan peningkatan kadar IL-10, serta menilai tingkat adesi yang terjadi, setelah laparotomi dan laparoskopi.

Metode: Penelitian ini adalah eksperimental laboratorium, dengan desain post test, menggunakan 12 kelinci New Zealand, setelah dilakukan adaptasi selama 1 minggu, dan dibagi menjadi 2 kelompok. Pada kelompok 1 (K1) dilakukan laparotomi dan abrasi pada ileum, sedangkan kelompok 2 (K2) dilakukan laparoskopi dan abrasi pada ileum juga. Pada semua kelompok diambil sampel darah vena sebelum dan 6 jam setelah perlakuan, untuk diperiksa kadar kortisol dengan metoda ELISA. Enam hari (hari ke-7) setelah pembedahan, semua subjek penelitian dari kedua kelompok dilakukan laparotomi untuk menilai derajat adesi yang terjadi dan juga dilakukan pemeriksaan kadar IL-10 dari cairan peritoneum. Uji statistk digunakan untuk menilai perbedaan kadar kortisol, IL10 dan derajat adesi antara kedua kelompok. Data diolah dan dianalisa dengan mengunakan SPSS.

Hasil : Terdapat perbedaan yang bermakna pada kadar kortisol, IL10 dan derajat adesi diantara kedua kelompok, $(p=0,021, p<0,001$, $p=0,002)$. Terdapat korelasi negatif (tinggi) antara kadar kortisol darah dengan IL-10 ( $r=-0,805, p=0,0)$, dan korelasi negatif yang bermakna antara kadar IL-10 dengan derajat adesi $(r=-0,833, p=$ 0,001).

Simpulan : Bedah laparoskopi dapat mengurangi efek stress sistemik dan respon imun, sehingga akan menurunkan kejadian adesi pasca bedah.
\end{abstract}

Kata kunci : Derajat adesi, kortisol, IL-10, laparotomi, laparoskopi 


\section{INTRODUCTION}

Peritoneal adhesions are fibrous adhesions (connective tissue) between the abnormal peritoneal surface adjacent, between the peritoneum viserale, as well as between the parietal peritoneum with the visceral. Adhesion can cause adhesions between intraperitoneal organs, either between adjacent bowel or adhesions between the intestine with the abdominal wall. ${ }^{1}$

Injury to the cell layer mesothel will result in the release of various cytokines and inflammatory mediators early by peritoneal mesothelium cells and vascular endothelium is injured. Cytokines produced is proinflammatory cytokines, such as: IL-1, TNF- $a$, and IL-6. As a result of the production of these cytokines, it will further stimulate the activity of the blood coagulation cascade system and suppress the activity of PA. Along with the production of these mediators, also stimulated the activation of the kinin system, complement, arachidonic acid pathway (including prostaglandins), the formation of thrombin, and the conversion of fibrinogen to fibrin.

Kinin system and prostaglandins to stimulate vasodilation, increased capillary permeability, phagocytosis of bacteria and other foreign substances by PMN cells within 24-48 hours, and stimulates migration of macrophages and monocyte chemo-attractant through, so debridement and inflammatory processes have been perfect..$^{2-4}$

Proinflammatory cytokines would decrease the activity of peritoneal plasminogen-activator and increases the activity inihibitornya (PAI-1,2,3, Protease, Nexin). The results of this activity through the coagulation cascade system will generate fibrin in the peritoneal cavity. The presence of fibrin will stimulate adhesion formation through increased fibroblast activity stimulated by the growth factor PDGF (platelet-derived growth factor) and TGF- $\beta$. Fibroblast cells and also will be deposed mesothel collagen fibers to form a fibrinous adhesion. Therefore this process is the initial phase of the healing process bioseluler the peritoneum..$^{5-6}$

IL-10 is a cytokine secreted by monocytes many, who have pleiotrofik effect on the immune system and inflammation. IL-10 was first known for its ability to inhibit activation and effector function of $\mathrm{T}$ cells, monocytes and macrophages. Interleukin-10 is thought to suppress the pro-inflammatory mediators and cytokines that activate peritoneal fibrinolytic processes, reduce neovascularization process, reduce the migration and proliferation of fibroblasts and collagen production thus formed fibrin deposits and prevent the formation of permanent fibrous adhesion. . $^{7-10}$

While histiogenesis process is the result of stages or phases of peritoneal healing after peritoneal tissue integration can be restored. Phases seen in the picture 2.4. ${ }^{10}$
In peritoneal healing there is a special thing that distinguishes the healing process of the skin, ie when the initial phase of inflammation and trauma has been resolved or can be eliminated, then the fibrin that is formed will be described again by the fibrinolisis. ${ }^{28,29}$ Balance settings on both the process performed by the role of cytokines. After working proinflammatory cytokines and inflammatory etiology causes can be addressed, then these cytokines will decrease its concentration in the peritoneum, because it is not reproducible by cells involved in inflammation. Furthermore, the role are cytokines that have antiinflammatory functions. These cytokines are IL-4 and IL10. Due to the increase in the concentration and activity of these cytokines, the activity of plasminogen activatorakan increased, whereas plasminogen activator inhibitor activity would be inhibited. The end result of the process is the process of fibrinolysis, thus fibrinous adhesion described again and do not form permanent adhesion. ${ }^{11-15}$

\section{METHODS}

This study is an experimental laboratory, with a post-test design approach using experimental animals as objects of research. Selected types of New Zealand rabbits with body size considerations are quite large so easy when performed laparoscopically. Experiments performed with simple randomized sampling. The study group was divided into two, namely the K1 group as the treatment group rabbits laparotomy group and treatment group K2 group as the group of rabbits were performed laparoscopy.

\section{Sample Population}

Experimental animals such as the type of New Zealand male rabbits were physically healthy, age 8-12 weeks with a body weight between 2500-3000 grams. Selection of a rabbit on the consideration of body size is large enough so that action can be expected laparoscopy done well there is an infection on the skin of the abdominal area before treatment, there were no adhesions or peritoneal infection before treatment. Selected male rabbits that were not affected hormonal and pregnancy. 8-12 weeks of age the young rabbits because rabbits are still in young adulthood, have immunological response will be quickly visible. Some previous researchers are also using the same criteria.

\section{Implementation Research}

12 male rabbits adapted in the laboratory with individually caged and given a standard feed ration for 1 week ad libitum.

Prior to anesthesia all rabbit blood sample taken for examination cortisol levels before surgery. Anesthesia 


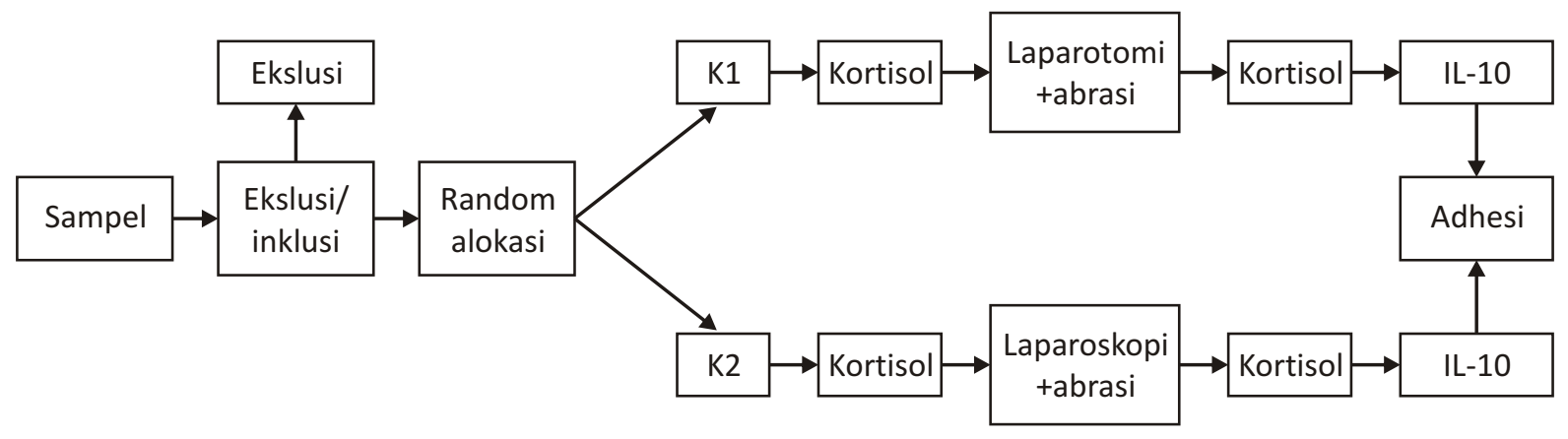

Figure 1. Flow of research process

wears ketamine $20 \mathrm{mg} / \mathrm{kg}$ and diazepam $1.5 \mathrm{mg} / \mathrm{kg}$. Actions performed aseptically using sterile instruments. Antibiotic prophylaxis is not given because it can affect the inflammatory reaction.

Treatment in accordance with their respective groups, namely:

a. Treatment group 1, laparotomy and abrasion along the terminal ileum $1 \mathrm{~cm}$ proximal from the ileocaecal junction towards, the anti-mesenterial side with laparoscopic forceps, surgical wound was closed with silk sutures $3 / 0$ wear one layer without sewing the peritoneum. Blood cortisol levels checked 6 hours post surgery.

b. Treatment group 2, performed laparoscopically with port size of $1 \mathrm{~cm}, 0.5 \mathrm{~cm}$ and $0.5 \mathrm{~cm}$, and abrasion along the terminal ileum $1 \mathrm{~cm}$ proximal from the ileocaecal junction towards, the anti-mesenterial side with laparoscopic forceps, surgical wound is closed with stitches one $3 / 0$ without wearing layers of silk sew the peritoneum. Blood serum cortisol levels checked 6 hours post surgery.

Postoperatively treated rabbits initially stable and get Ceftriaxone $3 \mathrm{mg} / 100 \mathrm{~g}$ of body weight intramuscularly every 24 hours for 3 days. Each rabbit that dead after the fourth day of the first postoperative laparotomy/laparoscopy, i performed laparotomy autopsy. While the rabbits that died before the fourth day after the laparotomy/laparoscopy, I excluded from the study and replaced by a new rabbit who meet the criteria. Each rabbit is dead recorded separately. The second laparotomy performed on day 7 to assess the degree of intraperitoneal adhesions. Rabbit is positioned upright (erect) for 15 minutes so that fluid in the peritoneal cavity collected at pelvic cavity. And then laparotomy incision is performed by means of \pm 5 $\mathrm{cm}$ vertical incision on the left side of the midline, then taken for examination of peritoneal fluid levels of IL10 , and an assessment of the degree of adhesion on the right side (the terminal ileum). Degree examination procedures intraperitoneal adhesions assessed according to the criteria of Nair et al.

\section{Data Analysis}

The data were processed and presented in tables and Boxplot. To determine the normality test of data normality using the Shapiro-Wilk test. When the data were normally distributed and homogeneous, for 2 different test samples were then analyzed using parametric paired Paired t-test and to test parametric Pearson correlation analysis. When full-laden parametric analysis is not met then the non-parametric analysis. Limit the degree of significance is that if $p 0.05$ with $95 \%$ confidence intervals. Data analysis was done using SPSS.

\begin{tabular}{|lcc|}
\hline $\begin{array}{l}\text { TABLE 1 } \\
\text { Mean of peritoneal adhesion }\end{array}$ & \\
Group & $\boldsymbol{n}$ & Mean \pm SD \\
\hline Group K1 & 6 & $3.17 \pm 0.408$ \\
Group K2 & 6 & $0.33 \pm 0.516$ \\
\hline
\end{tabular}

TABLE 2

Adhesion of different test groups based laparotomy and laparoscopy

\begin{tabular}{cccc} 
Group & Laparotomy & Laparoscopy & $\boldsymbol{p}$ \\
\hline Adhesi & $3(3-4)$ & $0(0-1)$ & $0.002^{*} ¥$ \\
\hline
\end{tabular}

* Signifikan $p<0.05$

$¥$ Mann Whitney test

\section{TABLE 3}

Mean of blood cortisol level

\begin{tabular}{llc} 
Group & $\boldsymbol{n}$ & Mean \pm SD \\
\hline Group K1 & 6 & $25.1 \pm 4.127$ \\
Group K2 & 6 & $18.73 \pm 3.920$
\end{tabular}


TABLE 4

Deskriptif and Normality of data Cortisol before and after surgery

Group

Mean \pm SD

Median

p

$(\min -\max )$

Cortisol before

Laparotomy

$7.28 \pm 3.015$

$7.73(2.21-10.4)$

0.583

Laparoscopy

$5.13 \pm 3.024$

$4.2(2.3-9.3)$

0.207

Cortisol after

Laparotomy

$25.1 \pm 4.127$

$26.3(17.5-29.11)$

0.232

Laparoscopy

$18.73 \pm 3.920$

$17.75(14.1$ - 23.6)

0.356

\begin{tabular}{|c|c|c|c|}
\hline Group & Cortisol pre & Cortisol post & $p$ \\
\hline Laparotomy & $7.28 \pm 3.015$ & $25.1 \pm 4.127$ & $0.001 * €$ \\
\hline Laparoscopy & $5.13 \pm 3.024$ & $18.73 \pm 3.920$ & $<0.001 * €$ \\
\hline
\end{tabular}

* Signifikan $p<0.05$

$€$ Paired t test

\section{TABLE 6}

Different test cortisol pre towards post on each - each treatment using Paired t-test

\begin{tabular}{llcc} 
Group & Laparotomy & Laparoscopy & $\boldsymbol{p}$ \\
\hline Cortisol & $25.1 \pm 4.127$ & $18.73 \pm 3.920$ & $0.021 * \pm$
\end{tabular}

* Signifikan $p<0.05$

$\mathrm{f}$ Independent $t$ test

\section{TABLE 7}

Different test cortisol pre towards post on each - each treatment using Paired t-test

\begin{tabular}{lccc} 
Group & Laparotomy & Laparoscopy & $\boldsymbol{p}$ \\
\hline Group K1 & $25,14,127$ & $25.1 \pm 4.127$ & $0.001^{*} €$ \\
Group K2 & $5.13 \pm 3.024$ & $18.73 \pm 3.920$ & $<0.001^{*} €$
\end{tabular}

\section{Result}

Treatment group 1 (K1), at the end of the study did not found a dead rabbit or included in the exclusion criteria, so the number of rabbits kept 6 rabbits until the end of the study. The results obtained in this group, intraperitoneal adhesions occurred at grade 3 and grade 5 rabbits rabbits 4 to 1 . Total average (mean) increase in cortisol levels 17 $827 \pm 5477 \mathrm{ng} / \mathrm{ml}$, and the average number (mean) levels of IL-10 peritoneal fluid was $23445 \pm 3512 \mathrm{pg} / \mathrm{ml}$. Treatment group 2 (K2), the amount of 6 rabbits, performed laparoscopically, at the end of the study obtained 1 dead rabbits on day five and still included in the inclusion criteria, the number of rabbits were kept alive until the tail end of the study 5 . The results obtained in this group, intraperitoneal adhesions occur grade 0 to 4 rabbits, grade 1 to 2 rabbits. The average amount of 

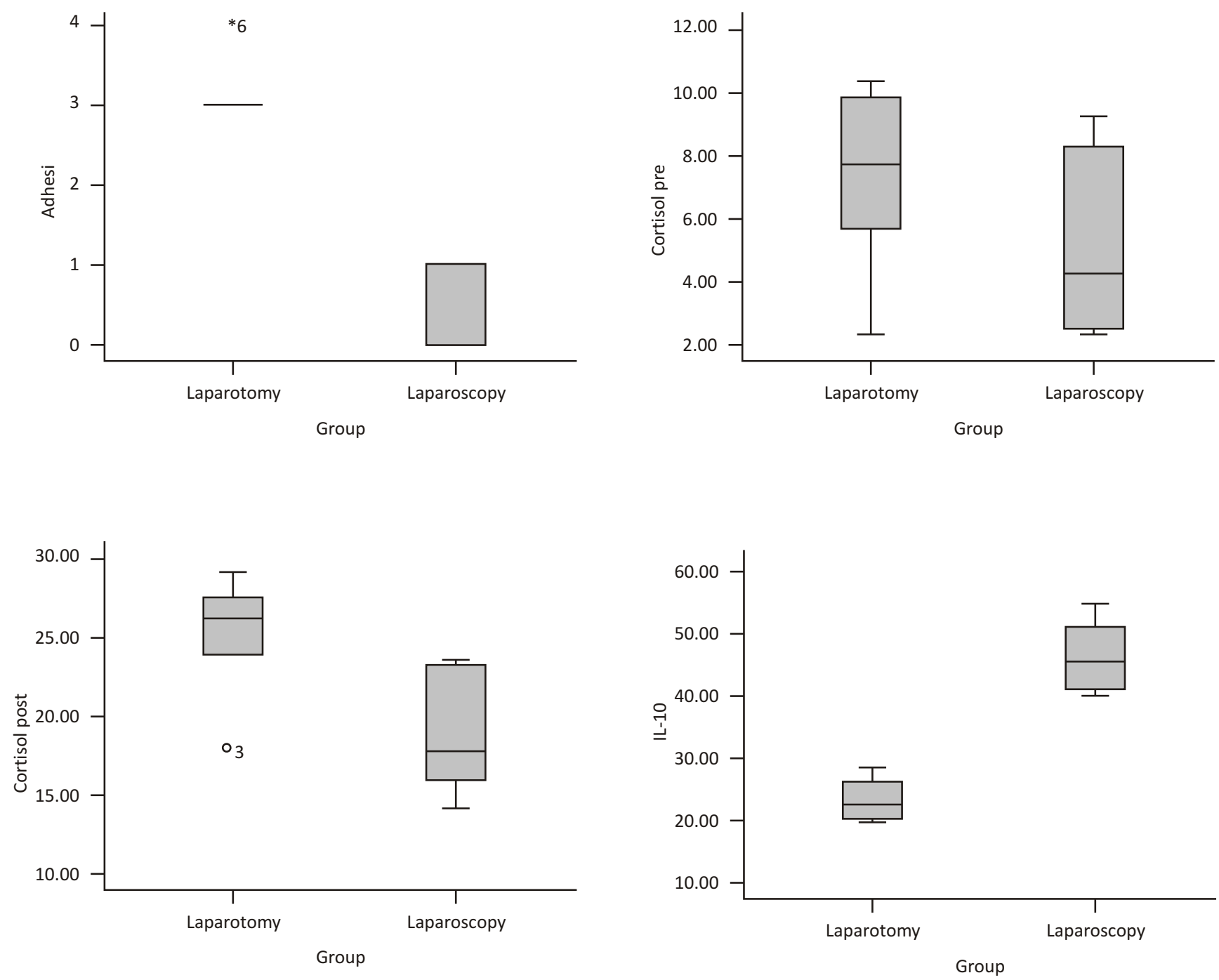

\begin{tabular}{lcc} 
TABLE 8 \\
Nilai Rerata Kadar IL-10 Cairan Peritoneum \\
Group & $\boldsymbol{n}$ & Mean \pm SD \\
\hline Group K1 & 6 & $23.445 \pm 3.512$ \\
Group K2 & 6 & $46.493 \pm 6.020$
\end{tabular}

increased levels of cortisol 13,600 $\pm 4,113 \mathrm{ng} / \mathrm{ml}$, and the average number (mean) levels of IL-10 peritoneal fluid was $46493 \pm 6020 \mathrm{pg} / \mathrm{ml}$.

\section{Degree of Peritoneal adhesion}

In each treatment group carried out corresponding predetermined. Based on the descriptive statistics obtained by the average degree of adhesion of intraperitoneal adhesions in group K1 degrees is 3:17 \pm 0.408 ; in the K2 group was $0.516 \pm 0: 33$. Showed that the mean degree of adhesion was lower in the group $\mathrm{K} 2$ than K1.

Variable degrees of adhesion test for normality with the Shapiro-Wilk intraperitoneal $(n<50)$ indicates that the variable is not normally distributed $(p<0.05)$, so as to know the different degrees of adhesion intraperitoneal each group performed a non-parametric test of difference.

Different test using bivariate nonparametric Mann-Whitney test $(p<0.05)$ showed that all treatment groups had significant difference with $p=0.002$.

\section{Blood cortisol level}

In each treatment group carried out corresponding predetermined. Based on the descriptive statistics obtained mean blood cortisol levels of blood cortisol levels in group K1 was $25.1 \pm 4.127 \mathrm{ng} / \mathrm{ml}$; in the K2 group was $18.73 \pm 3.920 \mathrm{ng} / \mathrm{ml}$. Showed higher mean cortisol levels than those in group K1 K2. 


\section{TABLE 9}

Different test IL-10

\begin{tabular}{lccc} 
Group & Laparotomy & Laparoscopy & $\boldsymbol{p}$ \\
\hline $\mathrm{IL}-10$ & $23.445 \pm 3.512$ & $46.493 \pm 6.020$ & $<0.001^{*} \mp$ \\
\hline
\end{tabular}

* Signifikan $p<0.05$

f Independent t test

\section{TABLE 10}

Blood Cortisol Levels correlation with levels of IL-10 Fluid peritoneum

\begin{tabular}{lccc} 
Variabel & Mean \pm SD & $\boldsymbol{r}$ & $\boldsymbol{p}$ \\
\hline Cortisol post & $21.92 \pm 5.078$ & -0.805 & $0.002 * \S$ \\
$\mathrm{IL}-1$ & $34.92 \pm 12.878$ & & \\
\hline
\end{tabular}

* Signifikan $p<0.05$

$\S$ Pearson Correlation

\section{TABLE 11}

Correlation Levels of IL-10 Fluid peritoneum with the Degree of Adhesion

\begin{tabular}{lccc} 
Variabel & Mean \pm SD & $\boldsymbol{r}$ & $\boldsymbol{p}$ \\
\hline IL-10 & $34.92 \pm 4.766$ & -0.855 & $<0.001^{*} \times$ \\
Adhesi & $1.75 \pm 1.545$ & & \\
\end{tabular}

* Signifikan $p<0.05$

q Spearman Correlation

\section{Mean of blood cortisol level}

Normality test blood cortisol levels with Shapiro-Wilk $(n<50)$ indicates that the variable is normally distributed $(p>0.05)$.

Homogeneity test variables using Levene's test $(p>0.05)$, the data obtained is homogeneous blood cortisol levels ( $p=0.21$ ), so as to know the different blood cortisol levels of each group performed different test parametric.

Different test cortisol pre towards post on each each treatment using Paired t-test $(\mathrm{p}<0.05)$ found a significant difference with $p=0.001$.

While different test blood cortisol levels post each each treatment using t-test Independent test $(p<0.05)$, found a significant difference with $p=0.021$.

\section{Levels of IL-10 Fluid peritoneum}

In each treatment group carried out corresponding predetermined. Based on descriptive statistics levels of IL-10 obtained an average of peritoneal fluid levels of IL10 in the peritoneal fluid K1 group is $23445 \pm 3512 \mathrm{pg} / \mathrm{ml}$; in the K2 group was $46493 \pm 6020 \mathrm{pg} / \mathrm{ml}$. Obtained results mean levels of IL-10 were higher in the group compared to the group K1 K2.
Normality test fluid levels of IL-10 with the Shapiro-Wilk peritoneum $(n<50)$ indicates that the variable is normally distributed $(p>0.05)$.

Homogeneity test variables using Levene's test ( $p>$ $0.05)$, the data obtained levels of IL-10 peritoneal fluid is not homogeneous $(p=0.000)$.

\section{Different test IL-10}

Bivariate difference test at variable levels of IL-10 peritoneal fluid by using test Independent $t$ test $(p<0.05)$ found a significant difference with $p<0.001$.

Blood Cortisol Levels correlation with levels of IL10 Fluid peritoneum.

\section{Correlation result}

Statistical analysis to determine the correlation between the levels of blood koertisol a numeric variable, with levels of peritoneal fluid IL-10 which is also the numerical variables, using Pearson's correlation test correlation $(p<0.05)$. Results of correlation test a significant association with the nature of the strong negative correlation $(r=-0.805)$ between blood cortisol levels and the levels of IL-10 in the peritoneal fluid of rabbits made 


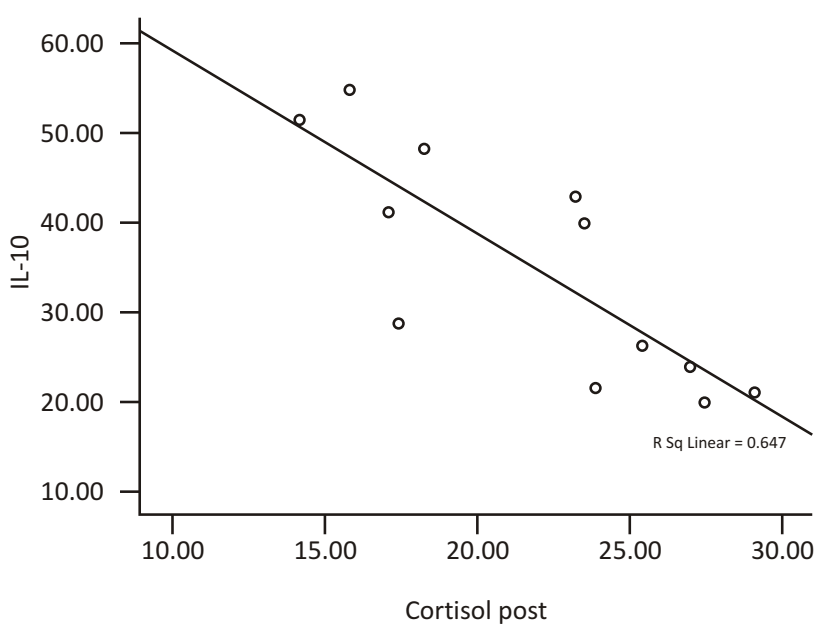

intraperitoneal adhesions with $p=0.002$, which means that the higher the blood levels of cortisol, the levels of IL10 the lower peritoneal fluid.

Correlation Levels of IL-10 Fluid peritoneum with the Degree of Adhesion.

Statistical analysis to determine the correlation between the levels of IL-10 peritoneal fluid which is a numeric variable, the degree of intraperitoneal adhesions that are ordinal variables, using the Spearman correlation test $(p=0.05)$. Correlation test results obtained against a very strong correlation $(r=-0.855)$ between the levels of IL-10 peritoneal fluid and the degree of intraperitoneal adhesions in rabbits made intraperitoneal adhesions with $p<0.001$, which means that the higher levels of IL-10 peritoneal fluid, the degree of the lower intraperitoneal adhesions.

\section{DISCUSSION}

Intraperitoneal adhesion formation experimentally can be done through various ways, namely ischemia models, the model of peritoneal injury, thermal injury models, with a foreign object, with chemicals and with Abrasion bakterial. ${ }^{22,29}$ Ileum in this experiment are included in the model of peritoneal injury. This method was chosen because of an injury caused by abrasion injury resembling the peritoneal injury during surgery of the abdomen. This study aims to prove the existence of a relationship between the type of abdominal surgery as laparotomy and laparoscopy in rabbits with peritoneal adhesion levels with parameters increase cortisol levels and decreased levels of IL-10, where all the rabbits made of abrasion ilium.

The study was conducted on 12 male rabbits of New Zealand, were randomly divided into two groups with each group number 6 rabbits. Six rabbits were

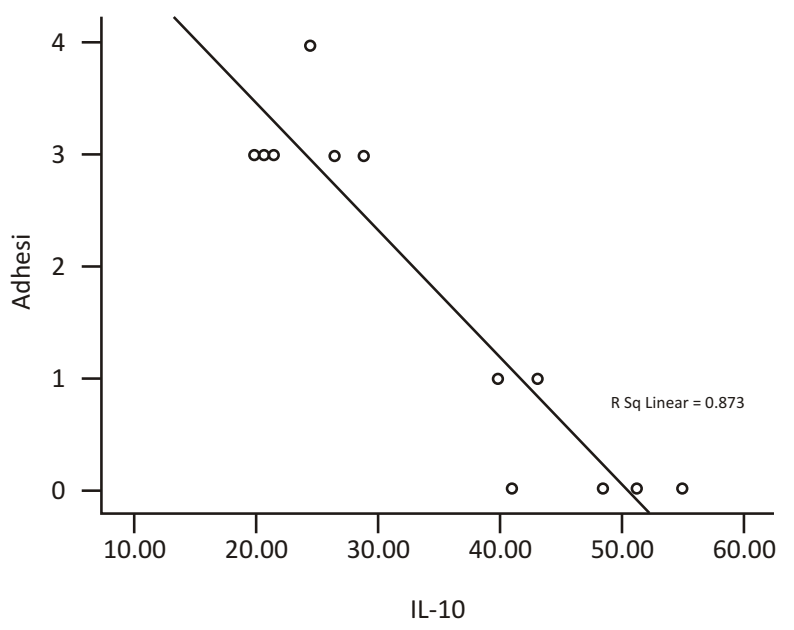

performed via laparotomy abrasion ileum (K1), 6 rabbits were performed through laparoscopic ileal abrasion (K2).

The results obtained in group 1, intraperitoneal adhesions occur in 5 grade 3 and grade 4 rabbits rabbits at 1. Total average (mean) degree of adhesion in group $\mathrm{K} 1$ is $3: 17 \pm 0.408$, an increase in cortisol levels $17827 \pm 5477$ $\mathrm{ng} / \mathrm{ml}$, and the average number (mean) levels of IL-10 peritoneal fluid was $23445 \pm 3512 \mathrm{ng} / \mathrm{ml}$. In the treatment group $2(\mathrm{~K} 2)$, the amount of 6 rabbits, performed laparoscopically, at the end of the study obtained 1 dead rabbits on day five and still included in the inclusion criteria, the number of rabbits were kept alive until the tail end of the study 5 . The results obtained in this group, intraperitoneal adhesions occur grade 0 to 4 rabbits, grade 1 to 2 rabbits. Total average (mean) degree of adhesion of this group is 0:33 $\pm 0.516 \pm 13,600$ increase in cortisol levels $4,113 \mathrm{ng} / \mathrm{ml}$, and the average number (mean) levels of IL-10 peritoneal fluid was $46493 \pm 6020$ $\mathrm{pg} / \mathrm{ml}$. The results of the statistical test (different test) on the degree of intraperitoneal adhesions $(p=0.002)$, blood cortisol levels $(p=0.021)$, and IL-10 levels of peritoneal fluid $(p<0.001)$, found significant differences between the groups were performed by laparotomy surgery laparoscopic surgery group. Laparoscopic surgery (minimally invasive) shown to produce smaller effects of stress, the levels of IL-10 were greater, and the degree of adhesion is minimal compared to laparotomy. Results of correlation between cortisol levels and blood levels of IL-10 in the peritoneal fluid of rabbits intraperitoneal adhesions that made a significant association with the nature of the strong negative correlation $(\mathrm{r}=-0.805)$ with $p=0.002$, which means that the higher the blood levels of cortisol, the levels of IL-10 the lower the peritoneal fluid.

Statistical analysis to determine the correlation between IL-10 levels and the degree of adhesion of 
peritoneal fluid using the Spearman correlation test $(p<0.05)$. Correlation test results obtained against a very strong correlation $(r=-0.855)$ between the levels of IL-10 peritoneal fluid and the degree of intraperitoneal adhesions with $p<0.001$, which means that the higher levels of IL-10 peritoneal fluid, hence the lower the degree of intraperitoneal adhesions.

Peritoneal adhesions can occur due to trauma to the peritoneum and stimulation peritoneum.Trauma inflammatory response (proinflammatory cytokines; IL1, IL-6, TNF-a) can be caused by things: trauma surgery, tissue ischemia, infection, reaction allergy, blood, foreign bodies irritating. ${ }^{22,33}$

IL-10 is a cytokine secreted by monocytes many, who have pleiotrofik effect on the immune system and inflammation. IL-10 was first known for its ability to inhibit activation and effector function of $\mathrm{T}$ cells, monocytes and macrophages. Interleukin-10 is thought to suppress the pro-inflammatory mediators and cytokines that activate peritoneal fibrinolytic processes, reduce neovascularization process, reduce the migration and proliferation of fibroblasts and collagen production thus formed fibrin deposits can dilisis and prevent the formation of permanent fibrous adhesion..$^{27}$

Adhesion is actually a natural consequence of the surgical trauma and healing. Surgical wound will trigger some reactions that lead to the formation of adhesion through the inflamation process. ${ }^{2,6}$

Surgical trauma stimulates a series of hormonal and metabolic changes in response to stress. Stress will cause the hypothalamus to secrete corticotropic-releasing hormone (CRH) $\mathrm{CRH}$-where it will be heading to the pituitary gland and causes the secretion of adrenocorticotropic hormone (ACTH) into the blood circulation. Will ACTH reaches the adrenal glands and causes the secretion of cortisol and anti-inflammatory effects immunosupresif. ${ }^{15-20}$

Cortisol also has other particular glucocorticoid effects associated with anti-inflammatory activity, which the cortisol accumulation of macrophages and neutrophils mengahambat in the area and can interfere with the synthesis of inflammatory mediators inflamasi. ${ }^{22,23}$

A disturbance in the affinity of fibrinolysis has been known as the cause of intraperitoneal adhesions. ${ }^{24}$

\section{CONCLUSION}

There is a significant difference in cortisol levels between rabbits that performed with laparotomy and laparoscopy. Obtained the mean levels of blood cortisol levels in group $\mathrm{K} 1$ was $25.1 \pm 4.127 \mathrm{ng} / \mathrm{ml}$; in the $\mathrm{K} 2$ group was $18.73 \pm 3.920 \mathrm{ng} / \mathrm{ml}$. Showed higher mean cortisol levels in group K1 than those K2.

There is a significant difference in the levels of IL10 between rabbits that performed with laparotomy and laparoscopy. Obtained the mean levels of IL-10 in the peritoneal fluid $\mathrm{K} 1$ group is $23445 \pm 3512 \mathrm{pg} / \mathrm{ml}$.; in the K2 group was $46493 \pm 6020 \mathrm{pg} / \mathrm{ml}$. Obtained results mean levels of IL-10 were higher in the group K1 compared to the group K2. Bivariate difference test at variable levels of IL-10 used peritoneal fluid Independent $t$-test $(p<0.05)$ found a significant difference with $p<0.001$.

There is a significant difference in the degree of adhesion between rabbits that performed with laparotomy and laparoscopy obtained the average degree of adhesion in group K1 is 3:17 \pm 0.408 ; in the K2 group was $0.516 \pm 0: 33$. Showed that the mean degree of adhesion was lower in the group K2 than K1, different non-parametric test used bivariate with Mann-Whitney test $(p<0.05)$ showed that all treatment groups had significant difference with $\mathrm{p}=0.002$.

There is a meaningful correlation with the strong negative correlation $(r=-0.805)$ between blood serum cortisol levels and the levels of IL-10 in the peritoneal fluid of rabbits made intraperitoneal adhesions with $p=0.002$, which means that the higher the blood levels of cortisol, the levels of IL-10 are lower.

There is a very strong opposite correlation $(\mathrm{r}=$ $0.855)$ levels of IL-10 between peritoneal fluid and the degree of intraperitoneal adhesions in rabbits made intraperitoneal adhesions with $p<0.001$, which means that the higher levels of IL-10 peritoneal fluid, the degree of adhesion intraperitoneal are lower.

\section{REFERRENCES}

1. Arung W, Meurisse M, Detry O. Pathophysiology and prevention of postoperative peritoneal adhesions. World J Gastroenterol. 2011;17(41): 4545-4553.

2. Ellis H, Moran BJ, Thompson JN, et al. Adhesion-Related Hospital Readmissions After Abdominal and Pelvic Surgery: a Retrospective Cohort Study. Lancet1999;353:1476-80.

3. Attard JP, MacLean AR. Adhesive Small Bowel Obstruction: Epidemiology, Biology and Prevention. Can J Surg 2007; 50(4):291-300.

4. Kamel RM. Prevention of Postoperative peritoneal Adhesions. Eur J Obgyn \& Reprod Bio 2010; 150:111-118.

5. Ellis H. The Clinical Significance of Adhesions :Focus on Intestinal Obstructions. Eur J Surg Suppl1997; 577:5-9. Available at http://www.ncbi.nlm.nih.gov/pubmed/ 9076446. Accessed at December 14th 2011.

6. Duron JJ, Berger A, Muscari F et al. Adhesive Postoperative Small Bowel Obstruction: Incidence and Risk Factors of Recurrence After Surgical Treatment. A Multicenter ProspectiveStudy.Annals Surg 2006; 244(5):750-7

7. Trew G. Consensus in Adhesion Reduction Management. The Obstetrician \& Gynaecologist 2004; 6(2):1-16.

8. Schippers E, Tittel A, Ottinger A, Schumpelick V. Laparoscopy versus Laparotomy: Comparison of Adhesion Formation after Bowel Resection in a Canine Model. Dig Surg 1998; 15: 145-7.

9. Hellebrekers BWJ, T. Kooistra. Pathogenesis of postoperative adhesion formation. British Journal of Surgery 2011; 98: 1503 1516.

10. Cheong YC, Laird SM, Shelton JB, et al. Peritoneal Healing and Adhesion Formation/Reformation. Human Reprod Update 
2001; 7:556-66.

11. Binnebösel M, Klink CD, Serno J, Jansen PL, von Trotha KT, Neumann UP, Junge K. Chronological evaluation of inflammatory mediators during peritoneal adhesion formation using a rat model. Langenbecks Arch Surg 2011;396:371378.

12. Friedrich M, Rixecker D, Friedrich G. Evaluation of stressrelated hormones after surgery. Clin Exp Obstet Gynecol. $1999 ; 26(2): 71-5 . \quad$ A v a i 1 a b l e a t http://www.ncbi.nlm.nih.gov/pubmed/10459440. Accessed at December 2nd, 2011

13. Harjai MM, Kumar A. Comparison of systemic stress response in open surgery versus laparoscopic surgery in children. J of Ped Surg Spec. 2010; 91: 63-8.

14. Diamond MP, Freeman ML. Clinical implications of postsurgical adhesions. Hum Reprod Update. 2001;7:567-576.

15. Veenhof AAFA, Sietses C, Von Blomberg BME, Van Hoogstraten IMW, Pas MHGM, Meijerink WJHJ, Peet DL, Tol MP, Bonjer HJ, Cuesta MA. The Surgical Stress Response and Postoperative Immune Function After Laparoscopic or Conventional Total Mesorectal Excision in Rectal Cancer: A Randomized Trial. Int J Colorectal Dis 2011; 26:5359.

16. Malik AM, Shah M, Pathan R, Sufi K. Pattern of Acute Intestinal Obstruction: Is There a Change in the Underlying Etiology? Saudi J Gastroenterol 2010;16(4):272-4.

17. Oladele AO, Akinkuolie AA, Agbakwuru EA. Pattern of Intestinal Obstruction in a Semiurban Nigerian Hospital. Niger J Clin Pract 2008; 11(4):347-50. Available at http://www.ncbi.nlm.nih.gov/pubmed/19320408. Accessed at January 23rd, 2011.

18. Ohene-Yeboah M, Adippah E, and Gyasi-Sarpong K. Acute Intestinal Obstruction in Adults in Kumasi, Ghana. Ghana Med $\mathrm{J} 2006 ; 40(2): 504$. A v a i 1 a b l e a t http://www.ncbi.nlm.nih.gov/pmc/articles/PMC1790839 Accessed at January 23rd, 2011.

19. Foster NM, McGory ML, Zingmond DS, Ko CY. Small bowel obstruction: a population-based appraisal. J Am Coll Surg $2006 ; 203(2): 170-6$. A v a i 1 a b l e a t http://www.ncbi.nlm.nih.gov/pubmed/16864029. Accessed at January 23rd, 2011.

20. Kössi J, Salminen P, Rantala A, Laato M. Population-Based Study of the Surgical Workload and Economic Impact of Bowel Obstruction Caused by Postoperative Adhesions.Br J Surg $2003 ; 90(11): 1441-4$. A v a i 1 a b l e a t http://www.ncbi.nlm.nih.gov/pubmed/14598429 Accessed at January 23rd, 2011.
21. Alibasjah S. Ileus Obstruktif : Sebuah Tinjauan. Disampaikan pada Muktamar IKABDI VI. Semarang 2002.

22. Liakakos T, Thomakos N, Fine PM, Dervenis C, Young RL. Peritoneal Adhesions: Etiology, Pathophysiology, and Clinical Significance. Dig Surg 2001; 18:260-73.

23. diZerega GS, Campeau JD. Peritonal Repair and Post-Surical Adhesion Formation. Human Reprod Update 2001; 7(6):547-55.

24. Lensvelt MMA, Brokelman WJA, Ivarsson ML, Falk P, Reijnen MMPJ. Peritoneal TGF $\beta-1$ Expression During Prolonged laparoscopic Procedures. Journal of Laparoendoscopic \& Advanced Surgical Tech.Vol. 20, No.6, 2010.

25. Dimopoulou I, Tzanela M, Vassiliadi D, Mavrou I, Kopterides $\mathrm{P}$, Orfanos S, et al. Pituitary-adrenal responses following major abdominal surgery. Hormones 2008, 7(3):237-242.

26. Sherwood L, Fisiologi Manusia Dari Sel ke Sistem, EGC, edisi 6, 2012; 766-7.

27. Alexander Zdanov, Structural Features of the Interleukin-10 Family of Cytokines, Current Pharmaceutical Design, 2004, 10, 3873-3884.

28. Hanafi B. Patogenesis, Pencegahan dan Pengelolaan Adhesi Intraperitoneum Paska Bedah. Disampaikan pada Muktamar IKABDI VI. Semarang 2002.

29. Gomel V, Urman B, Gurgan T. Patophysiology of Adhesion Formation and Strategies for Prevention. J Reprod Med 1996;41:35-41.

30. Nair SK, Bhat IK, Aurora AL: Role of proteolytic enzyme in the prevention of postoperative intraperitoneal adhesions. Arch Surg 1974;108: 849853.

31. Celik A, Erkan A, Ergul E, Bekar ME, Kusdemir A. Which is Most Effective in Prevention of Postoperative Intraperitoneal Adhesion Methylene Blue, Low molecular Weight Heparin or Vitamin A: An Experimental Study in Rats. The Internet Journal of Surgery 2008;15(1).

32. Ronan A Cahill and H Paul Redmond, Cytokine orchestration in post-operative peritoneal adhesion formation, World J Gastroenterol. 2008 August 21;14(31):4861-4866.

33. Elabscience, Rabbit UFC ( Rabbit Free Cortisol) ELISA Kit. Catalog No: E-EL-RB0046.96T

34. Elabscience, Rabbit IL-10 (Interleukin 10 ) ELISA Kit. Catalog No: E-EL-RB1496.96T 